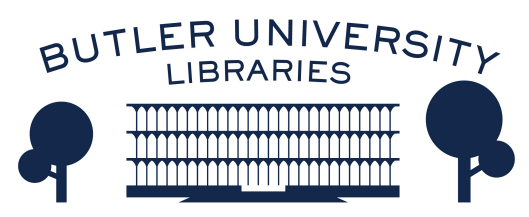

Journal of Hindu-Christian Studies

Volume 6

Article 10

January 1993

\title{
Viewpoints: The Human, the Environment: Sundry Questions
}

Murray Rogers

Follow this and additional works at: https://digitalcommons.butler.edu/jhcs

Part of the Religion Commons

\section{Recommended Citation}

Rogers, Murray (1993) "Viewpoints: The Human, the Environment: Sundry Questions," Journal of HinduChristian Studies: Vol. 6, Article 10.

Available at: https://doi.org/10.7825/2164-6279.1079

The Journal of Hindu-Christian Studies is a publication of the Society for Hindu-Christian Studies. The digital version is made available by Digital Commons @ Butler University. For questions about the Journal or the Society, please contact cbauman@butler.edu. For more information about Digital Commons @ Butler University, please contact digitalscholarship@butler.edu. 


\title{
VIEWPOINTS
}

\section{The Human, the Environment: Sundry Questions}

\author{
Murray Rogers
}

THIS PIECE IS not authoritative, definitely not! It is all wonderments, the sharing of puzzles and questions and then, from time to time, of wonder. That is why the real vehicle of such an essay is worship, that mysterious activity within the human which is from the beyond.

Naturally enough our subject is known to us all in our two traditions, Hindu and Christian, for however much in these latter centuries we may have grown used to looking at and considering our environment, it is never quite lost on us that we are the environment! One is tempted to question the appropriateness of 'talking about', 'writing about' what is inextricably oneself. And, crazily enough, having said that, I continue!

In whatever culture we may be born, do we not, each of us, experience the same 'beginning'? We are a part of our mothers and it is an agony to awake to any separateness; birth is that emerging separateness and yet, mercifully, a rupture which is never complete. Our Mother, our personal mother and our Mother Earth, are one and inseparable and the wonder begins at once on our emerging from the womb. Didn't every Vedic mother stand at the door of her mud or wattle dwelling with her baby in her arms and at the first glimpse of the orb of the sun each sunrise sing the Gayatri:

We meditate upon the glorious splendour of the Vivifier divine.
May he himself illuminate our minds! OM (RV III,62,9\&10)

Not that the new member of the human community understood the words but, as day followed day, she or he surely caught beyond words and concepts - an intuition of this comprehensive self, herself, inseparable from mother, from the sun and the earth, the wind and the water? Did not that tiny person begin to know and to experience what so many of us moderns take years to know deeply, that 'nothing is itself without everything else'?

And mustn't it have been the same for people of.Vedic times as of any age, the same with fire, agni? Wasn't the fire of the hearth in the home and the fire of the sacrifice, the place where all worlds meet, the seed of all that is, including the small person in the arms of his mother? When Raimundo Panikker writes of 'radiance and cosmic refulgence', of how 'with fiery brightness, like a lover of Dawn, he has linked the two worlds with the light of heaven' (RV 1,69) is he not seeing embraced in the cosmic fire of sacrifice the whole of creation, with no one and nothing excluded?

I magnify the Lord, the divine, the Priest; minister of the sacrifice, the offerer, supreme giver of treasure

$$
\text { (RV I, 1). }
$$

That same Vedic child is still with us; maybe six or seven years old now. The songs of his mother have been much extended by 
now by the chanting of the Vedas, the reading of the Upanishads. We wouldn't imagine that he understands mentally, maybe he never will, but he tastes and feels and is the food, the earth, the wind, the cattle, the water. Surely food is given by God and if the symbolism of that gift is disregarded, there will be great loss, for it certainly comes from the earth, from trees and plants and from human work, and to know the Earth is to know God; moreover, to receive our daily food from the earth, our mother, is to sense that we are ourselves food, food for others, food to be consumed by others.

\section{We, with the Lord of the Field as our friend \\ and helper, obtain for our cattle and horses \\ food in plenty, that they may be sleek and well-fed. \\ May he graciously grant us his favour!} (RV IV,57)

How natural it is, therefore, to see one's relationships in the human family as comparable to relationships among the cattle; all parts of creation are relatives:

Of one heart and one mind I make you, devoid of hate.

Love one another, as a cow

loves the calf she bore.

(AV III,30)

There is indeed a growing into one and that is a practical and real possibility for everyone precisely because all things spring from the One. The awakening of human consciousness gives birth both to separation, a differentiation from the other, and also growth towards integration and towards unity. After all this is uni-verse, an extraordinary invitation to communion, an invitation to experience the environment, including oneself, in terms of friendship and intimacy. In the Vedic experience wasn't this a personal possibility because of the One who 'stands before all people, revealing his face everywhere'? (Svet. Upanishad V.II,16)

With such a 'progression' opening up before our Vedic youngster, is it surprising that he (or she) is introduced to the power and transformation that issues from worship? Nature, creation, the human, and the relationship of one to the other, and of all to the One, can only be lived and breathed through worship and sacrifice. The Vedas (so it seems to me, very much a beginner in such Scriptures) exhibit this vivifying link again and again, e.g.
When came the mighty Waters,
bringing with them
the universal Germ, when sprang the
Fire,
thence leapt the God's One Spirit into
being.
What God shall we adore with our oblation?
$(\mathrm{RV}, 121,7)$

Men and women become the 'lords of many treasures' by the grace and work of the Atman, the Spirit. As Prajapati discovered in his long pilgrimage (Chandogya Upanishad) 'it is because of the light of the Spirit that the human mind can see, and can think, and enjoy this world ... The man who on this earth finds and knows the Atman, his own Self, has all his holy desires and all the worlds and all joy'.

Would our Vedic ancestors have felt strangely at home if they had heard the modern authors Brian Swimme and Thomas Berry say in the final call of their great work The Universe Story:

We are discovering anew our human capacity for entering into the larger community of life, something that we have not experienced in any adequate manner since our Neolithic origins. This new experience enables us to activate the more extensive dimensions of our own being. Indeed our individual being apart from the wider community of being is emptiness. Our individual self finds its most complete realization within our family self, our community self, our species self, our earthly self, and eventually our universe self. (p.268)

Then, in our imagination, we cross time and space and find another small human on 
her mother's knee. This time the little person is in the western hemisphere and in the Christian era. It may relativise our differences to recognise that in fact the religious group to which each of us belongs depends to such a great extent upon where we are born on this planet! Tragically, when we grow up, we too often absolutise those differences and even kill in order to declare our superiority!

Our mother and her child are together; their 'worlds' intermingle. Mother sings 'The Lord is my shepherd; there is nothing I shall want' (Psalm 23) or perhaps they are outside their cottage door when the sun rises and mother remembers another poet's words:

The heavens proclaim the glory of God and the firmament shows forth the work of his hands.

Day unto day takes up the story and night unto night makes known the message (Psalm 18)

She knows deep down that she and humanity in general are a part of a whole orchestra of praise, comprising the sun, the moon and stars, the whole earth and the sea, as also the living creatures, the animals, the plants and the trees, each one of which 'utters praise'. All, not only human beings, are created to lift up their hearts in praise that the love of the Lord may reach to the ends of the earth. Is it any wonder that the mountains 'skip like rams' and 'the little hills like lambs'? (Psalm 114)

Mother is unlikely to express such a patently obvious fact, but she knows that human life and every other form of life, in heaven, on earth or under the earth, including the oceans, can only exist together in a marvelous comprehensive spiritual and material system. She knows nothing of the intricacies of planetary connections, but she knows well enough, and deeper than superficial consciousness, that there is a Whole, an All which simply is, without beginning or end, and she murmurs to this All, still rocking the child on her knees,
In the morning fill us with your love. We shall be glad and rejoice all our days. (Psalm 89)

So as to prove her point to this new member of the human family, she lifts the baby to her breast and feeds her!

For such, a century or two ago, or even today in any happy corner which has not been 'eroded' by 'development', we human beings do not stand apart from nature. We are simply one component of the whole; we are the environment in its marvelous and infinite variety. And when, later, the child hears the stories and parables of Jesus of Nazareth, told then by word of mouth and now sung or read from the Gospels, the same feeling for the earth is plainly conveyed. Jesus 'goes up a mountain' and teaches the people; he borrows the boat of some fishermen friends, for the crowd is great, and continues the teaching from the rowing boat. $\mathrm{He}$ belongs to village society and, naturally enough, the taste of his stories is all of plants and animals, of birds and of the seasons. No church buildings for him but an out-of-door life, 'breathing' the Presence and Life of the Father.

Later, for the fellowship of the friends of Jesus - for it should be remembered that the great international Church institutions are of much later origin - it was the gathering around the Bread and Wine, mysteriously become the very life of God, that the central 'moment' of existence happened. There, in sacrament and sacrifice, matter and spirit are revealed as one, the human and his environment are, as at the beginning, united, universe becomes communion and the 'fullness of being' becomes realised.

And yet, and yet ... way back, well before the time of Jesus in Palestine, there was another stream of awareness, of revelation, men said, which in more recent centuries has been turned to human 'advantage', giving the human a superiority over the rest of creation. Was it not said; in the very first chapter of the Bible, in the account of creation, that God, having made everything 
in the earth and sky and sea, last of all made 'man in his own image, after our likeness, and let them have dominion over the fish of the sea, and over the birds of the air, and over the cattle, and over all the earth, and over every creeping thing that creeps upon the earth' (Genesis 1:26)? The patriarchal, male-centred (too often totalitarian) rule over nature was born from such a word and started to wreak havoc in people's minds!

Subsequently an attitude of domination and control is found not infrequently, as in Psalm 8 for example, where we sometimes sing thoughtlessly:

You have made him (man) little less than a god;

With glory and honour you crowned him,

gave him power over the works of your hand,

put all things under his feet.

All of them, sheep and cattle, yes, even the savage beasts, birds of the air, and fish

that make their way through the waters.

The natural world has in that Psalm become already a resource for man's use. The way of manipulation was opened; the male dominance centred in control and power was given divine authority which is claimed so strongly in our churches and societies today - and not, sadly enough, in the western world only.

True, men were to be stewards of all resources, 'under God', for $\mathrm{He}$ alone remained Lord and Master. Tragically, as faith became dim and the industrial plundering of the planet increased, this emphasis on 'stewardship' has been so largely forgotten that the world as a communing experience has been superseded. The reciprocity between Mother Earth and the human component has been ignored and forgotten and the Earth is suffering a collapse brought on by man's exploitation. It is plainly not enough for us humans to see ourselves as stewards; our hubris, encouraged by our almost unlimited technological skills, is so overwhelming that only by seeing ourselves as derivatives and planetary health as primary will we escape disaster to this mysteriously wonderful earth given to us to share.

As Swimme and Berry say in their study of nature and science (The Universe Story) 'religion begins to appreciate that the primary sacred community is the Earth community. The human community becomes sacred through its participation in the larger planetary community' (p.257). These same authors challenge our religious traditions, a challenge echoed (at least so it seems to the present writer) by countless men and women grown suspicious of the tendency of all our religious traditions to fall back in such times on our respective fundamentalisms, while being painfully subservient in practice to our worldwide industrial and money-centred culture. Could it be that such a crisis calls us to a new religious tradition, to what has been called 'a new comprehensive context for all religions'? May it even be that, unbeknownst to us, such is being prepared in the womb of history in these so critical times for our universe of which you and I are still a responsible part?

For silent pondering:

O Hidden Life vibrant in every atom, O Hidden Light shining in every creature, O Hidden Love embracing all in Oneness, May each who feels himself as one with Thee, Know he is also one with every other. Annie Besant

As I go into the Earth, she pierces my heart. As I penetrate further, she unveils me. When I have reached her center, I am weeping openly. I have known her all my life, yet she reveals stories to $\mathrm{me}$, and these stories are revelations and I am transformed.

$$
\text { Susan Griffin }
$$

We shall not cease from exploration and the end of all our exploring shall be to arrive where we started and know the place for the first time.

T.S. Eliot (Little Gidding) 